Article

\title{
How does Perceived Destination Social Responsibility Impact Revisit Intentions: The Mediating Roles of Destination Preference and Relationship Quality
}

\author{
Lujun $\mathrm{Su}^{1}$ and Yinghua Huang ${ }^{2, *(1)}$ \\ 1 School of Business, Central South University, Changsha 410083, China; sljslj0616@csu.edu.cn \\ 2 Department of Hospitality, Tourism and Event Management, San Jóse State University, San Jóse, CA 95192, USA \\ * Correspondence: yinghua.huang@sjsu.edu
}

Received: 21 November 2018; Accepted: 23 December 2018; Published: 27 December 2018

check for updates

\begin{abstract}
This study applied the relationship quality theory to examine how destination social responsibility (DSR) impacts revisit intentions through the mediation of destination preference and relationship quality (i.e., tourist satisfaction and identification). An integrated model was proposed and tested by using survey data from an urban tourism attraction in China. The findings indicate that DSR positively impacts destination preference and tourist satisfaction, but it does not have a significant influence on tourist-destination identification. Destination preference directly affects tourist satisfaction and tourist-destination identification, which in turn positively influences revisit intentions. This study offered theoretical and practical contributions to the research of destination social responsibility.
\end{abstract}

Keywords: destination social responsibility; destination preference; tourist satisfaction; tourist-destination identification; revisit intentions

\section{Introduction}

Tourism development can lead to many benefits, such as increasing employment, investments, the growth of local business [1], as well as tax revenue [2]. For this reason, many countries promote tourism as a key area of economic policy, which leads to an intensification of destination competition. As competition increases among destinations, it will become increasingly important for tourism managers and marketers to understand their target visitors better. Therefore, it is very important to articulate the decision-making processes of tourists, and the driving factors of a tourist's destination loyalty [3,4]. Mao and Zhang [4] suggested that "a theoretical justification for loyalty formulation should be discussed by explaining the customers' decision-making or choice alternatives" (p.202). Generally, the formation process of tourist behavior can be divided into three stages: pre-visit, in-visit, and post-visit [5]. Thus, it may be a useful tool to investigate the driving factors of destination loyalty based on these three stages.

Perceived corporate social responsibility built on the company's past activities has been confirmed to have important effects on customer attitudes and behaviors [6]. Destination social responsibility (DSR) activities demonstrate how the destination cares about its stakeholders' benefits, which may help to decrease tourists' perception of travel risk when they choose destinations [7]. For example, a destination social responsibility initiative like care of tourist's interests, can make the traveler feel satisfactory, and adopt positive behaviors [7]. Thus, this study adopted destination social responsibility as the antecedent of revisit intentions. 
The marketing literature widely used preference to measure the effect of brand equity, and adopted it as the predictor of the intention to choose and purchase a brand [8]. Confirmed brand preference is a symbolic predictor for consumers' purchases [9]. The tourism literature also suggested that destination preference would impact tourists' travel decisions [4]. However, few studies have investigated the importance of destination preference, and explored the relationship between destination preference and tourist loyalty [4]. Only Mao and Zhang [4] pointed out that "the literature pertaining to the relationship between destination preference (DP) and destination loyalty (DL) is rather limited. To what extent DP affects the loyalty of tourists in a favorable way requires further investigation. Such an investigation is deemed to be important, as a proven close relationship between DP and loyalty could reform the marketing goals of tourist destinations in the future. Furthermore, the relationship between DP and satisfaction also currently suffers from a lack of investigation" (p. 201). To fill this gap, the current study investigates the role of destination preference to revisit intentions.

Relationship marketing encompasses transaction marketing and seeks to build long-term trust and mutually beneficial relationships with valued customers [10]. According to Reichheld and Sasser [11], by maintaining a relationship with customers, companies can increase their profits by almost $100 \%$ by retaining just 5\% more of their customers. Just as Meng and Elliott [12] pointed out, "relationship quality is increasingly emerging as a strategy for organizations that strive to retain loyal and satisfied customers in today's highly competitive environment" (p.509). With the intensification of tourism marketing competition, some researchers have also put forward the use of relationship marketing strategy to realize tourist loyalty, in turn enhancing the competitiveness of destination $[10,13,14]$.

Relationship quality is a key concept of relationship marketing, because it measures the strength of a relationship, and can predict customer behavior $[13,15]$. In the tourism literature, the relationship quality between tourists and the destination consists of two components: tourist satisfaction and tourist-destination identification [14]. Although many studies have examined the antecedents and outcomes of tourist satisfaction, the role of tourist-destination identification as one important component of relationship quality has not received enough attention [10,14]. To fill this research gap, this study investigates the antecedents (i.e., DSR and DP) and consequences (i.e., revisit intentions) of tourist-destination identification. This study contributes to the body of knowledge by revealing the mediating role of tourist-destination identification among DSR, DP, and revisit intentions. The existing literature of corporate social responsibility (CSR) has shown that CSR activities are a powerful means for communicating a company's values, and customers are more likely to compare their own values with those of the company, and develop a sense of identification to a socially responsible company [16-18]. However, little research has investigated the relationships of social responsibility, customer-organization identification, and customer loyalty in the context of a tourism destination. Because destination social responsibility initiatives involve collective efforts of all stakeholders (e.g., tourism companies, local residents, destination management organizations), the mechanism of DSR, and its impacts on tourist behaviors are more complex and warrants further investigation [7].

Overall, this study addresses the questions of whether and how destination social responsibility, destination preference, and relationship quality (tourist satisfaction, tourist-destination identification) influence revisit intentions according to the tourist decision process: pre-visit, in-visit, and post-visit. Taken collectively, the contributions of this study are fourfold. First, it divides the formation process of tourist behavior into three stages, namely, pre-visit, in-visit, and post-visit, and constructs an integrated model to investigate the drivers of revisit intentions. Second, based on the marketing literature, this paper adopts destination preference as the antecedent of revisit intentions, and examine its role between destination social responsibility and relationship quality. Third, based on the relationship quality theory [19], the present study uses tourist satisfaction and tourist-destination identification to represent the relationship between tourists and the destination, and explores the role of tourist-destination identification, which is generally ignored by researchers. Fourth, using mediating and multiple mediating analyses, this study examines the effects of destination social responsibility on revisit intentions, to enrich our understanding of the formation process of revisit intentions. 
This article is organized as follows: The next section provides an overview of relationship quality theory and the variables studied, and then develops the hypotheses. In Section 3, the study methodology is presented, followed by the measures and data analysis in Section 4. Finally, after the discussion, managerial strategies, limitations, and further research directions are offered.

\section{Literature Review and Hypotheses Development}

Based on relationship quality theory, this study proposed a conceptual model to investigate the antecedents (i.e., DSR and DP) and consequence (i.e., revisit intentions) of relationship quality (i.e., tourist satisfaction, tourist-destination identification). This section provides a literature review for each construct in the proposed model, and proposes hypotheses based on relationship quality theory and the findings of previous studies.

\subsection{Destination Social Responsibility}

Tourism development has social, cultural, and environmental impacts, including both positive and negative ones [20]. Objectively, it is necessary for tourism enterprises to adopt social responsibility initiatives to reduce the negative impacts of tourism growth [7]. Thus, researchers have studied the CSR of airlines [21] hotels [22], restaurants [23], and other tourism and hospitality companies. However, the CSR concept is "not completely suitable to the destination context" [20], because the social responsibilities of a destination involve all interrelated stakeholders and require their collective efforts to promote environmental sustainability. While CSR focuses on a single company, DSR examines the collective efforts of all destination stakeholders (e.g., government, companies, local residents) from a holistic perspective. Given such difference, Su et al. [20] introduced the DSR concept to describe the collective ideology and the efforts of destination stakeholders to conduct socially responsible activities as perceived by tourists.

In the global tourism market, destinations are promoted as a single entity that combines all services and infrastructure that are needed for the arrival and stay of visitors, and offer tourist experience [24]. From the tourists' perspective, each destination is evaluated as a holistic organization when tourists make travel decisions [7]. Because the sustainable development of a destination requests the participation and collaboration of all stakeholders, including both private and public sectors, tourists would perceive DSR as a result of the collective and accumulative efforts of all stakeholders involved [20]. For example, if a company engages in doing small things to reduce waste, we might not be able to aware of the impacts of their socially responsible behaviors. However, if every single person and company at the destination does their own small part to reduce waste, the combined impacts can be significant and notable. Therefore, the concept of DSR does not measure the social responsibility activities of stakeholders separately [25]. In this study, DSR is an overall evaluation of all stakeholders' social responsible activities from the tourists' perspective.

\subsection{Destination Preference}

Brand preference is a key to study consumer choice behavior [26], and many studies have confirmed that preference will impact customers' attitudes and choices $[8,26]$. Especially, brand preference has been recognized as a good predictor of the customer intention to choose and purchase the products of a brand $[9,27]$. Thus, brand preference has been adopted as an indicator of customer loyalty in some studies of the shopping decision-making process [8]. In the tourism marketing context, some studies suggested that tourism marketing strategies should understand how tourists make their travel decisions [4]. Because preference would impact people's decision, scholars introduced the preference construct into the destination context, and defined the concept of destination preference as the relative preference for choosing and visiting a destination $[4,28]$. In the destination selection process, destination preference is a direct antecedent of destination choice [4]. Based on previous literature $[4,7,14]$, this study investigates the relationships among destination social responsibility, 
destination preference, relationship quality (i.e., tourist satisfaction, tourist-destination identification), and revisit intentions.

\subsection{Relationship Quality}

Differing from transactional marketing, relationship marketing emphasizes the development and maintenance of long-lasting relationships between the customers and companies [29,30]. The concept of relationship quality was introduced by Kotler et al. [31] to assess the strength of a relationship [32,33]. In the business-to-business setting, relationship quality has been defined as "the degree to which buyers are satisfied over time with the overall relationship as manifested in product quality, service quality, and the price paid for the value received and the degree to which the relationship functions as a partnership" [19]. In the context of customer service, relationship quality is considered as "customer perceptions and evaluations of individual service employees' communication and behavior, such as respect, courtesy, warmth, empathy, and helpfulness." [10]

Despite the diverse perspectives of relationship quality in different settings, there is agreement that relationship quality is a "higher-order construct consisting of several distinct, although related dimensions" [34]. According to Bhattacharya and Sen [15], the strongest relationships between customers and companies are grounded in the identification phenomenon. Since individuals have the need of developing self-identity in the world, a customer may identify himself or herself with a company, which in turn strengthens the consumer-company relationship [15]. In the context of travel and tourism consumption, Su, Swanson, and Chen [14] indicate that the relationship between tourists and the destination includes tourist satisfaction and tourist-destination identification.

In the hospitality and tourism industries, the nature of human interaction and service inseparability offer many opportunities for service providers to implement relationship marketing strategies. The service delivery process of hospitality and tourism companies is characterized by the high intensity of human interactions. Tourists develop their relationships with a company based on how they were treated through every service encounter. Previous studies show that servers' attributes (e.g., likeability, expertise, customer orientation) and the process of mutual disclosure between customers and servers are key factors influencing relationship quality $[12,13]$. Therefore, many hospitality and tourism companies emphasize on training employees' customer orientation, professional expertise, and effective communication skills for building customer relationships $[10,19]$. Building on prior studies $[14,15]$, the current study considers the relationship quality as an overall evaluation of the strength of the relationship between tourists and the destination, which comprises two components-tourist satisfaction and tourist-destination identification.

In the hospitality and tourism industries, the nature of human interaction and service inseparability offer many opportunities for service providers to implement relationship marketing strategies. The service delivery process of hospitality and tourism companies is characterized by a high intensity of human interactions. Tourists develop their relationships with a company based on how they were treated through every service encounter. Previous studies show that servers' attributes (e.g., likeability, expertise, customer orientation) and the process of mutual disclosure between customers and servers are key factors influencing relationship quality [12,13]. Therefore, many hospitality and tourism companies emphasize on training employees' customer orientation, professional expertise, and effective communication skills for building customer relationship $[10,19]$.

\subsubsection{Tourist Satisfaction}

As one type of post-purchase attitude [35], satisfaction has been adopted to evaluate previous service experience, product performance, community residential experience, or tourism experience in a destination $[5,36]$. One prevailing definition of satisfaction is "the summary psychological state resulting when the emotion surrounding disconfirmed expectations is coupled with the consumer's prior feeling about the consumption experience" [37]. Many tourism researchers, however, prefer the 
term of overall satisfaction, which is defined as "an overall evaluation based on the total purchase and consumption experience with a good or service over time." [38]. In this study, tourist satisfaction is defined as in Oliver [37]: it is a psychological state stimulated by perceptions about the destination, and can predict tourist revisit intentions.

In the marketing literature, satisfaction has been recognized as one of the key components of relationship quality, which has important impacts on customer loyalty [5,37]. Many researchers have examined the determinants of customer satisfaction, and have suggested that perceived service quality and customer's expectation are powerful predictors of satisfaction [25,32]. In a recent study, Tran et al. [25] found that DSR can also affect tourist satisfaction through the mediation of emotion.

\subsubsection{Tourist-Destination Identification}

The concept of customer-company identification has its roots in theories of social identity and organization identification. According to social identity theory, people tend to go beyond their personal identity to develop a social identity for articulating their sense of self [39,40]. The person-organization identification will be formed when a person perceives the sense of "oneness or belongings" with an organization [41]. Organization identification represents the degree to which an individual perceived himself or herself and the organization as sharing the same defining attributes [42]. In the studies of social psychology and organizational behavior, identification is believed to satisfy the need for social identity and self-definition, and then it positively influences many organizational behaviors, such as employees' citizenship behaviors and employee loyalty [43,44].

Bhattacharya and Sen [15] introduced the concept of identification into the marketing domain, and developed a conceptual framework of customer-company (C-C) identification, which defined C-C identification as "an active, selective, and volitional act motivated by the satisfaction of one or more self-definitional (i.e., "Who am L?") needs" (p.77). Previous research has found that customers can identify with a company because they have self-definitional needs [15,42,45]. For example, Su et al. [20] introduced customer-company identification into the tourism context, and confirmed that tourist-destination identification has an important mediating role between perceptions and behavioral intentions.

\subsection{Revisitation of Intentions}

Consumer loyalty has been an important goal of service of providers, due to the high lifetime value of loyal customers, and the high cost of acquiring new customers [46]. Correspondingly, consumer loyalty has been recognized as a major concept of sustainable competitive advantage, which can increase a firm's market share and allow it to remain profitable [47]. Retaining existing customers usually has a much lower cost than winning new ones [48]. The intentions to revisit a destination are the most important loyal behaviors that represent the possibility of revisiting the same destination in the future [48,49]. Thus, this study selected revisit intentions as the outcome variable in the proposed model.

\subsection{Hypotheses Development}

Brand preference is one type of predisposition by customers towards certain brands, which summarize consumers' cognitive information processing towards brand stimuli [50]. Therefore, brand stimuli are considered as one important source of establishing consumer preference [26,51]. Perceived destination social responsibility can be an external stimulus [7]. Thus, we assume that DSR leads to tourist preference with the destination. Though no study has directly examined the effect of DSR on destination preference, Lim and Weaver [52] found that destination image, the important consequence of destination social responsibility, positively impacted tourists' preference for the destination. Liu et al. [8] confirmed the effect of corporate social responsibility on customer-based brand preference. Based on the above discussion, we provide the following hypothesis: 
Hypothesis 1. Destination social responsibility positively affects destination preference.

Based on institutional theory [53] and stakeholder theory [54], a consumer plays multiple roles as not only an economic being, but also a member in his or her family and community [6]. Therefore, the term of "generalized customer" was used to denote that customers may not just care about their consumption experiences, because they also can be a part of stakeholder groups who care about other issues related to societal well-being [55]. As a result, such generalized customers are found to be likely to prefer the products and service offered by those companies who take more social responsibilities [6]. Meanwhile, if a company has established a good record of CSR actions, the consumers are likely to develop a positive attitude towards the company $[6,56]$.

In the tourism context, many destination management organizations have engaged in social responsibility activities. Some common practices of DSR include minimizing the tourism carbon footprint, adopting responsible environmental standards in tourism attractions, offering certifications of sustainable destination, evaluating the sustainable practices of hospitality and tourism companies, and so on. As a result of these DSR initiatives, the destinations would sustain long-term economic, environmental, and social development, which in turn would provide a better tourism experience for the tourists. Therefore, the tourists may become more satisfied with the destination, because the overall environment and tourism ecosystem has been improved by the DSR campaigns. Based on these previous findings, the current study posits the following hypothesis:

Hypothesis 2. Destination social responsibility positively affects tourist satisfaction.

Tourist-destination identification is described as a psychological state deriving from the overlap between tourists' perceived self-identity and destination identification. On the basis of social recognition theory and self-categorization theory [57], tourists divide themselves automatically into one social category in which they have a belonging feeling. To a large extent, when customers realize that firms have norms and values that are consistent with their self-concept, they are likely to gain the destination identification [43,58].

The higher levels of CSR customers perceived, the more they have company identification $[16,59,60]$. Scott and Lane [61] proposed that customers tend to identify with those firms whose principles and common values are similar to theirs. Some researchers also claimed that the CSR initiatives of firms could enhance customers' company identification, leading to a tight link between the customer and the company [60,62].

In the hospitality literature, Martínez and del Bosque [16] found CSR initiatives have a positive influence on company identification. Hui et al. [63] also confirmed that the customer perceptions of CSR positively affected customer-company identification. Similarly, in the tourism setting, DSR initiatives can enhance tourists' destination identification [7]. DSR initiatives usually cover a variety of plans and actions to protect the environment, improve social welfare, promote the local economy, or protect tourists' rights. Tourists, as social members, may share common social value standards and ethical views as proposed in DSR initiatives. Therefore, a tourist could identify himself or herself with the tourism destination when the DSR initiatives match the person's value view. Thus, we developed the following hypothesis:

\section{Hypothesis 3. Destination social responsibility positively affects tourist-destination identification.}

Jamal and Al-Marri [64] suggest that customers are likely to be more satisfied with most preferred brands than with the least preferred brands, and their empirical findings support their assumption. After studying Chinese tourists in Australia, Mao and Zhang [4] suggested that destination preference would impact tourist satisfaction, and their empirical findings also supported this assumption. Therefore, we consider destination preference as an outcome of a tourist's cognitive judgment that affects the satisfaction with the destination. Besides, destination preference arises pre-visit, and tourism 
satisfaction arises based on tourism experience in-visit; when preference is the realized, the satisfaction with tourism will be higher. Therefore, we proposed the following hypothesis:

Hypothesis 4. Destination preference positively affects tourist satisfaction.

Although no study has directly examined the relationship between destination preference and tourist-destination identification, some studies have identified how tourist perceptions and attitudes would affect tourist identification [7,63]. Destination preference is a favorable attitude toward a place, and often leads to positive word-of-mouth and emotions [4]. When tourists have a preference for a destination, the destination should have a certain type of consensus with tourists' hobbies, interests, personality, and values. Thus, the preferred destination can be better able to meet the needs of tourists, and lead to tourists thinking themselves as a part of the destination, and categorizing themselves in the destination group. Based on this, tourists adopt the identity of the destination with which they have categorized themselves. Thus, we infer that destination preference could result in tourists identifying with the destination. Therefore, the following hypothesis is formulated:

Hypothesis 5. Destination preference positively affects tourist-destination identification.

In the organizational literature, some studies have confirmed that satisfaction with the organization would result in organizational identification [44,65]. In the marketing literature, some studies have also found that customer satisfaction is the antecedent of customer identification [66].

Satisfaction may lead to a reevaluation of the salience of identities, in that positive feelings and emotions are the bases of the formation, maintenance, and development of identification [67]. Satisfied tourists with positive affective states have a greater possibility of feeding a deep rapport and sense of belongingness towards a visited destination [68] and will construct or strengthen their identity in relation to the destination [69]. Indeed, Hultman et al. [69] indicated that tourist satisfaction positively related to identification. Therefore, we propose the following hypothesis:

Hypothesis 6. Tourism satisfaction positively affects tourist-destination identification.

Through the development of long-term, mutually beneficial relationships with customers, customer retention and loyalty have become possible [15]. There are many factors that drive customer loyalty; however, the relationship quality is widely confirmed that it plays a key role in customer loyalty [20,70-72]. In the tourism and hospitality literature, the relationship between satisfaction and revisit intentions are widely confirmed, such as cruise passenger [73], golf traveler [3], island tourist [74], heritage tourist [5,48], and rural tourist [75]. It shows that the more satisfied with the tourism experience at the destination, the higher intentions to revisit the destination [76]. Therefore, the following hypothesis is proposed:

Hypothesis 7. Tourism satisfaction positively affects revisit intentions.

C-C identification has been recognized as an antecedent of company loyalty, customer resilience to negative information, and customer acquirement [15]. In the literature of organizational behavior, many studies have suggested that employees' identification with an organization contributes to lower turnover [42,58]. Ahearne, Bhattacharya and Gruen's empirical findings indicated that customer-company identification positively influences customer behavior, both product utilization, and extra-role behavior [77]. Just as Ahearne, Bhattacharya, and Gruen [77] pointed out, "from a social identity standpoint, once a customer identifies with a company, purchasing that company's products becomes an act of self-expression" (p.577).

In the marketing literature, previous research also found C-C identification impacts customer loyalty $[13,16,78-80]$. Based on social identity theory [57] and self-categorization theory [81], customers 
who identified themselves with the company would psychologically attach to the company [15], and in turn become more loyal to the company $[16,79,80]$. In the tourism context, Su et al. [20] found that tourist-destination identification has a positive effect on revisit intentions. Recently, Kumar and Kaushik [82] also confirmed that destination brand identification affects tourists' loyalty toward tourism destinations. These discussions lead to the following hypothesis:

Hypothesis 8. Tourist-destination identification positively affects revisit intentions.

According to the formulation process of tourist behavior, this study divides the process into three stages: pre-visit, in-visit, and post-visit [83-86]. Based on this and the hypotheses, the following conceptual model represents the network of relationships among destination social responsibility, destination preference, relationship quality (tourist satisfaction, tourist-destination identification), and revisit intentions (Figure 1).

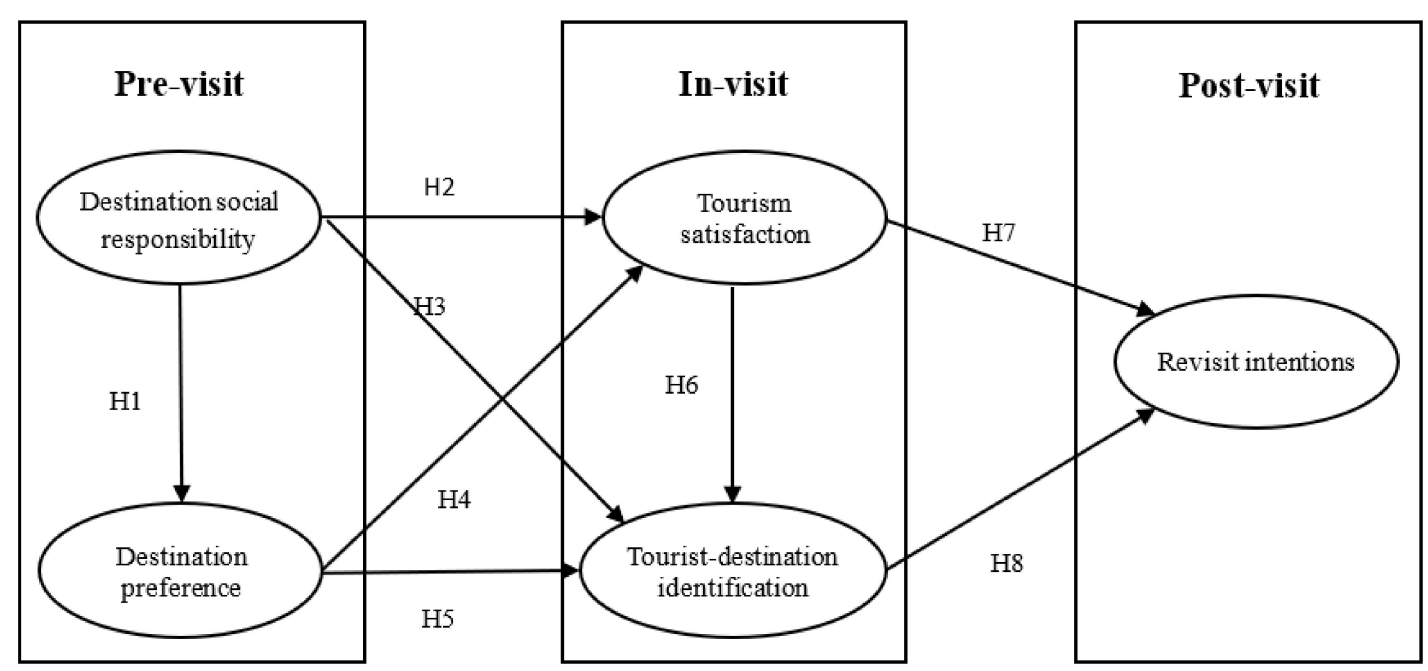

Figure 1. The proposed model.

\section{Methodology}

\subsection{Construct Measurement}

According to an analysis of 37 definitions of CSR by Dahlsrud [87], CSR includes five aspects: environmental, social, economic, stakeholder, and voluntariness dimensions. In the DSR literature, some studies also develop similar dimensions to measure DSR [7]. Therefore, the current study measures DSR by using five adapted items that evaluate the environmental, social, economic, stakeholder, and voluntariness dimensions. This scale has shown good validity and reliability in previous studies $[7,20,88]$.

Destination preference is the relative preference for choosing and visiting the destination. Based on Liu et al.'s [8] brand preference scale, and Mao and Zhang's [4] destination preference scale, this study adopted four items to measure the destination preference.

Tourist satisfaction is an overall evaluation of the tourism destination [7], which is measured with three items adapted from Brown, Cowles, and Tuten [89]. This scale has shown solid reliability and validation in heritage tourism and the heritage destination context in China [90].

For tourist-destination identification, the scale of organizational identification by Mael \& Ashforth [44] was adopted. The scale is well-established, and has demonstrated good reliability in previous studies [7]. Four items were adopted to measure tourist identification towards the destination.

Revisit intentions were captured by a three-item scale adapted from Hutchinson et al. [3], and it showed good reliability and validity in the heritage destination context [90]. 
The scales ranged from "Extremely disagree" (1) to "Extremely agree" (7); however, for tourist satisfaction, the scale ranged from "Extremely unsatisfactory" (1) to "Extremely important" (7).

\subsection{Pre-Test of the Measurements}

A pretest was conducted before the formal survey. First, we asked five experts in tourism marketing to examine the survey questionnaire. Then, we revised the survey according to their feedback. Next, we distributed the revised questionnaire to 40 undergraduate students studying at a top-tier university in China. They were asked to fill in the questionnaire, and the results from them were used to analyze the reliability and validity of the measurement items. Cronbach's Alpha was used to assess the reliability of a measurement instrument. Then, standard factor loading was used to assess the validity of measurement items. The results showed that Cronbach's Alpha of each latent construct was bigger than 0.700 , representing solid reliability [91]. The standard factor loading of each item was bigger than 0.500 , and significant at the 0.001 level, which indicated the adequate validity [92].

\subsection{Data Collection}

A survey was conducted in three visitor service areas near the exit in September and October 2016. Fifteen college students were trained as survey investigators to participate in data collection. These survey collectors were divided into three equal-sized teams. All survey collectors were instructed regarding the goals of the current study, and given background information of Yuelu Mountain where data collection was to occur. Instructions were provided regarding how to courteously invite adult respondents to participate in the study. The survey collectors were dressed in uniforms with a logo from a reputable regional university. Each team was assigned to one of three different service areas at Yuelu Mountain on a rotating schedule at different times during a four-week period. A total of 600 questionnaires were distributed, and 522 valid responses were collected ( $92.23 \%$ valid rate).

Yuelu Mountain is a national AAAAA scenic area that lies in the west bank of Xiangjiang in Changsha city. The scenic area is composed of many beautiful natural and cultural attractions, including Yuelu Mountain and the nearby rivers, gardens, ponds, plants, animals, and cultural attractions. The scenic area administration department has been promoting several DSR initiatives in recent years. Thus, it is a popular place for tourists and suitable for conducting the study.

Yuelu Mountain promotes its socially responsible actions by a variety of communication channels. The information on DSR initiatives is included in visitor brochures, websites, social media, and signages at various locations within the site. For example, signages have been used to remind visitors of appropriate behaviors to protect its natural environment and cultural heritage. To establish a unified image, all tourism service providers (e.g., restaurants, hotels, retail shops, etc.) within the site have adopted consistent signages, a unified logo, and color scheme. Also, press releases about protecting the environment and charitable efforts have been regularly published through local news outlets and shared on its website.

\subsection{Data Analysis Method}

SPSS 22.0 (Beijing, China) and AMOS 22.0 (Beijing, China) were used to analyze data. Measurement quality was evaluated using a measurement model. Then, we use Structural Equation Modeling (SEM) to assess the adequacy of the theoretical model, to test the hypothesized relationships among study constructs, and to conduct a modeling comparison between the theoretical model and the competition model.

\subsection{Sample Description}

Table 1 presents the respondents' demographic profiles. The sample had a balanced ratio of males $(52.5 \%)$ and females (47.5\%). Most respondents were young people: namely, 35.1\% were 18 to 24 years 
of age, and $31.8 \%$ were 25 to 44 . Most respondents had received a college education, and $10.0 \%$ of them had a postgraduate degree. Responses reported a wide range of monthly incomes, ranging from less than 2000 RMB, to 5000 RMB. First-time visitors accounted for $39.3 \%$, while $32.4 \%$ of respondents had visited the place more than five times.

Table 1. The socio-economic and demographic characteristics of the sample.

\begin{tabular}{|c|c|c|c|c|c|}
\hline & $\mathbf{n}$ & $\%$ & & $\mathbf{N}$ & $\%$ \\
\hline Age & \multicolumn{5}{|c|}{ Monthly Income } \\
\hline 18 to 24 & 183 & 35.1 & Less than $2000 \mathrm{RMB}$ & 211 & 40.4 \\
\hline 25 to 44 & 166 & 31.8 & 2000 to $2999 \mathrm{RMB}$ & 52 & 10.0 \\
\hline 45 to 64 & 116 & 22.2 & 3000 to $3999 \mathrm{RMB}$ & 89 & 17.0 \\
\hline \multirow[t]{2}{*}{65 or Older } & 57 & 10.9 & 4000 to 4999 RMB & 65 & 12.5 \\
\hline & & & 5000 RMB or More & 105 & 20.1 \\
\hline \multicolumn{6}{|l|}{ Gender } \\
\hline Male & 274 & 52.5 & & & \\
\hline \multirow[t]{2}{*}{ Female } & 248 & 47.5 & & & \\
\hline & & & Visiting times & & \\
\hline Education & & & First Time & 205 & 39.3 \\
\hline Less than High School & 34 & 6.5 & Two Times & 52 & 10.0 \\
\hline $\begin{array}{c}\text { High School/Technical } \\
\text { School }\end{array}$ & 91 & 17.4 & Three Times & 50 & 9.6 \\
\hline $\begin{array}{c}\text { Undergraduate/Associate } \\
\text { Degree }\end{array}$ & 345 & 66.1 & Four Times & 46 & 8.8 \\
\hline Postgraduate Degree & 52 & 10.0 & Five Times or More & 169 & 32.4 \\
\hline
\end{tabular}

\section{Empirical Analysis}

\subsection{Common-Method Bias Test}

Harman's single-factor method was used to test whether the common method bias exists. Using SPSS 22.0, we conducted an exploratory factor analysis to examine all of the measurement items. The results revealed five factors, and the factor with the largest eigenvalue explained $46.317 \%$ of the total variance. Since $46.317 \%$ is lower than $50 \%$, this test result indicates that this study does not have a problem of common method bias [93].

\subsection{Multivariate Normality Test}

Before the analysis of the measurement model, we examined the multivariate normality to see whether it satisfies SEM assumptions. The results showed that the absolute values of univariate skewness were below 2 , and that the absolute values of univariate kurtosis were below 3 . Thus, it meant the data did not extremely deviate from a normal distribution [94].

\subsection{Measurement Model}

To test the conceptual model, we adopted a two-step analysis process. The first step was to conduct the confirmatory factor analysis (CFA) to verify the measurement model. Then, the second step was to examine the proposed inter-variable relationships.

\subsubsection{The Indices of the Measurement Model}

The fit of the measurement model suggests that the model fit the data very well. The $\chi^{2} / d f$ was 2.486, less than 3, and the RMSEA value was 0.060, less than 0.08. GFI $=0.927$, AGFI $=0.902$, $\mathrm{NFI}=0.948, \mathrm{IFI}=0.938, \mathrm{TLI}=0.959, \mathrm{CFI}=0.966$, and all of them were bigger than 0.900 . Based on the model assessment criteria by $\mathrm{Hu}$ and Benter [95], all of the values were acceptable. Therefore, we can consider that the measurement model fit the data well. 


\subsubsection{Reliability Testing}

We used Cronbach's alpha coefficient and the composite construct reliability to check the measuring reliability. Table 2 presents the results, revealing that the Cronbach's alpha of constructs is from 0.873 to 0.925 , or far more than 0.700 . At the same time, the composite reliability of constructs was from 0.874 to 0.926 , which was greater than the threshold for indicating reliability, as suggested by Fornell and Larcker [96]. Therefore, we considered that the measurement scale of each construct has adequate internal consistency [97].

\subsubsection{Validity Testing}

We tested the convergent validity by assessing the contribution of measurement items to constructs. Convergent validity was found to be adequate, as all items factor loadings were greater than 0.674 , and were significant at 0.001 . At the same time, the average variance extracted (AVE) of all constructs ranged from 0.600 to 0.898 , higher than the minimum criterion of 0.500 . This result indicates that a large portion of the variance was explained by the constructs [96,97]. All of this suggests that there is enough convergent validity of the measurements.

Discriminant validity reflects whether a construct significantly shares information with the other construct or not. To test discriminant validity, we compared the correlation coefficient between constructs with the square root of AVE [96]. If the squared correlations between any pair of constructs are smaller than AVE, it indicates that discriminant validity is satisfied [96]. As shown in Table 3, all correlation coefficients are less than 0.762, and all the square root of AVE is bigger than 0.774, which means all correlation coefficients are less than all square root of AVE. Thus, the discriminant validity is satisfactory. 
Table 2. The results of the measurement model.

\begin{tabular}{|c|c|c|c|c|c|c|c|c|}
\hline Construct & Items & Mean & $\begin{array}{c}\text { Standard } \\
\text { Deviation }\end{array}$ & $\begin{array}{c}\text { Standard } \\
\text { Loading }\end{array}$ & T-Statistic & $\begin{array}{l}\text { Composite } \\
\text { Reliability }\end{array}$ & $\begin{array}{c}\text { Average } \\
\text { Variance Extracted } \\
\end{array}$ & $\begin{array}{l}\text { Cronbach's } \\
\text { Alpha }\end{array}$ \\
\hline \multirow{5}{*}{$\begin{array}{c}\text { Destination } \\
\text { social responsibility }\end{array}$} & $\begin{array}{l}\text { The destination management organization and service providers of } \\
\text { Yuelu Mountain are environmentally responsible }\end{array}$ & 5.60 & 1.265 & 0.775 & 20.225 & \multirow{5}{*}{0.880} & \multirow{5}{*}{0.600} & \multirow{5}{*}{0.881} \\
\hline & $\begin{array}{l}\text { The destination management organization and service providers of } \\
\text { Yuelu Mountain give back to the local community }\end{array}$ & 5.49 & 1.287 & 0.816 & 21.812 & & & \\
\hline & $\begin{array}{l}\text { The destination management organization and service providers of } \\
\text { Yuelu Mountain are successful in generating and allocating their } \\
\text { tourism revenues }\end{array}$ & 5.46 & 1.262 & 0.674 & 16.691 & & & \\
\hline & $\begin{array}{l}\text { The destination management organization and service providers of } \\
\text { Yuelu Mountain treat their stakeholders well }\end{array}$ & 5.51 & 1.285 & 0.802 & 21.271 & & & \\
\hline & $\begin{array}{l}\text { The destination management organization and service providers of } \\
\text { Yuelu Mountain act ethically and obey all legal obligations to fulfill their } \\
\text { social responsibilities }\end{array}$ & 5.75 & 1.242 & 0.797 & 21.090 & & & \\
\hline \multirow{4}{*}{ Destination preference } & Yuelu Mountain would easily be my first choice for a journey & 5.46 & 1.178 & 0.792 & 20.875 & \multirow{4}{*}{0.874} & \multirow{4}{*}{0.634} & \multirow{4}{*}{0.873} \\
\hline & Yuelu Mountain is more attractive than any other destination & 5.07 & 1.348 & 0.802 & 21.265 & & & \\
\hline & I am more interested in visiting Yuelu Mountain than other destinations & 5.43 & 1.214 & 0.818 & 21.902 & & & \\
\hline & $\begin{array}{l}\text { I still intend to visit Yuelu Mountain, even if other destinations offer a } \\
\text { better tourism experience }\end{array}$ & 5.29 & 1.306 & 0.775 & 20.237 & & & \\
\hline \multirow{3}{*}{ Tourist satisfaction } & Overall, I was satisfied with my visit to Yuelu Mountain & 5.47 & 1.295 & 0.878 & 25.030 & \multirow{3}{*}{0.926} & \multirow{3}{*}{0.898} & \multirow{3}{*}{0.925} \\
\hline & $\begin{array}{l}\text { Compared to my expectations, I was satisfied with my visit to } \\
\text { Yuelu Mountain }\end{array}$ & 5.34 & 1.245 & 0.911 & 26.582 & & & \\
\hline & $\begin{array}{l}\text { Compared to an ideal situation, I was satisfied with my visit to } \\
\text { Yuelu Mountain }\end{array}$ & 5.31 & 1.314 & 0.904 & 26.242 & & & \\
\hline \multirow{4}{*}{$\begin{array}{l}\text { Tourist-destination } \\
\text { identification }\end{array}$} & I am very interested in what others think about Yuelu Mountain & 4.85 & 1.442 & 0.793 & 21.321 & \multirow{4}{*}{0.921} & \multirow{4}{*}{0.744} & \multirow{4}{*}{0.919} \\
\hline & Yuelu Mountain's success is my success & 4.63 & 1.434 & 0.884 & 25.236 & & & \\
\hline & $\begin{array}{l}\text { When someone says positive things about Yuelu Mountain, it feels like a } \\
\text { compliment to myself }\end{array}$ & 4.78 & 1.535 & 0.900 & 26.016 & & & \\
\hline & When someone criticizes Yuelu Mountain, I would feel embarrassed & 4.84 & 1.457 & 0.869 & 24.585 & & & \\
\hline \multirow{3}{*}{ Revisit intentions } & I intend to revisit Yuelu the destination again & 5.39 & 1.477 & 0.793 & 21.586 & \multirow{3}{*}{0.931} & \multirow{3}{*}{0.819} & \multirow{3}{*}{0.926} \\
\hline & It is very likely that I will revisit the destination in the future & 5.05 & 1.566 & 0.981 & 30.449 & & & \\
\hline & The likelihood of my return to the destination for another travel is high & 5.02 & 1.614 & 0.931 & 27.741 & & & \\
\hline Goodness-of-fit & $\chi^{2} / d f=2.486$, RMSEA $=0$ & GFI $=$ & AGFI $=0$ & $\mathrm{NFI}=0$. & $=0.938,7$ & $\mathrm{CFI}=0.9$ & & \\
\hline
\end{tabular}

Table 3. The correlation coefficient and average variance extracted.

\begin{tabular}{|c|c|c|c|c|c|}
\hline & Destination Social Responsibility & Destination Preference & Tourist Satisfaction & Tourist-destination Identification & Revisit Intentions \\
\hline Destination social responsibility & 0.774 & & & & \\
\hline Destination preference & 0.624 & 0.796 & & & \\
\hline Tourist satisfaction & 0.584 & 0.762 & 0.898 & & \\
\hline Tourist-destination identification & 0.403 & 0.508 & 0.523 & 0.863 & \\
\hline Revisit intentions & 0.343 & 0.499 & 0.467 & 0.555 & 0.905 \\
\hline
\end{tabular}

Note: square root of the average variance extracted (AVE) is shown on the diagonal of the matrix; inter-construct correlations are shown off the diagonal. 


\subsection{Structural Model}

\subsubsection{Structural Model Fitting Indices}

The fitting indices of the structural model show that $\chi^{2} / d f=2.890$, RMSEA $=0.060$, GFI $=0.924$, AGFI $=0.900$, NFI $=0.947$, RFI $=0.937$, IFI $=0.965$, TLI $=0.958$, CFI $=0.964$. According to Hu and Bentler's [95] criteria, the fitting indices are acceptable, which means the structural model fits the data very well.

\subsubsection{Hypotheses Testing}

Table 4 demonstrates the results of the structural model. The impacts of destination social responsibility on destination preference $\left(\lambda_{21}=0.624, \mathrm{p}<0.001\right)$ and tourist satisfaction $\left(\lambda_{31}=0.177\right.$, $\mathrm{p}<0.001)$ are significant, but no significant impact was found for tourist-destination identification $\left(\lambda_{31}=0.086, \mathrm{p}>0.05\right)$. Therefore, the findings support Hypothesis 1 and Hypothesis 2 , but do not support Hypothesis 3.

With regard to the relationship destination preference and relationship quality, the results indicate that destination preference significantly influences tourist satisfaction $\left(\beta_{32}=0.654, p<0.001\right)$ and tourist-destination identification $\left(\beta_{42}=0.234, \mathrm{p}<0.05\right)$ respectively. Therefore, Hypothesis 4 and Hypothesis 5 are proven.

Tourist satisfaction significantly affected tourist-destination identification $\left(\beta_{43}=0.294, p<0.001\right)$ and revisit intention $\left(\beta_{53}=0.254, \mathrm{p}<0.001\right)$ respectively. Thus, Hypothesis 6 and Hypothesis 7 are supported.

With regard to the relationship between tourist-destination identification and revisit intentions, it shows a significant effect $\left(\beta_{54}=0.435, \mathrm{p}<0.001\right)$, which supports Hypothesis 8 . 
Table 4. Structural model evaluation indices and hypothesis testing outcomes.

\begin{tabular}{|c|c|c|c|c|c|c|}
\hline Hypothesis & Relationships Between Variables & Label of Path & Standard Path Loadings & T-Value & Standard Error & Hypothesis Test Outcome(Y/N) \\
\hline Hypothesis 1 & Destination social responsibility $\rightarrow$ Destination preference & $\lambda 21$ & $0.624^{* * *}$ & 12.689 & 0.046 & YES \\
\hline Hypothesis 2 & Destination social responsibility $\rightarrow$ Tourist satisfaction & $\lambda 31$ & $0.177^{* * * *}$ & 3.724 & 0.056 & YES \\
\hline Hypothesis 3 & Destination social responsibility $\rightarrow$ Tourist-destination identification & $\lambda 41$ & 0.086 & 1.498 & 0.065 & NO \\
\hline Hypothesis 4 & Destination preference $\rightarrow$ Tourist satisfaction & $\beta 32$ & $0.654^{* * *}$ & 12.182 & 0.068 & YES \\
\hline Hypothesis 5 & Destination preference $\rightarrow$ Tourist-destination identification & $\beta 42$ & $0.234^{* *}$ & 2.966 & 0.096 & YES \\
\hline Hypothesis 6 & Tourist satisfaction $\rightarrow$ Tourist-destination identification & $\beta 43$ & $0.294^{* * *}$ & 4.025 & 0.069 & YES \\
\hline Hypothesis 7 & Tourism satisfaction $\rightarrow$ Revisit intentions & $\beta 53$ & $0.254^{* * *}$ & 5.451 & 0.046 & YES \\
\hline Hypothesis 8 & Tourist-destination identification $\rightarrow$ Revisit intentions & $\beta 54$ & $0.425^{* * *}$ & 8.507 & 0.052 & YES \\
\hline
\end{tabular}

Note: ${ }^{* *}$ means significant at the level of $0.01{ }^{* * *}$ means significant at the level of 0.001 . 


\subsubsection{The Explanation of the Model}

The values of $0.01,0.09$, and 0.25 , respectively, indicate the little, medium, and powerful predicting abilities of the model [98]. As shown in Figure 2, the model explained 38.9\%, 60.4\%, 30.9\%, and $35.8 \%$ of the variance of destination preference, tourist satisfaction, tourist-destination identification, and revisit intentions, respectively. Thus, the results mean that the large effects of exogenous variables on the endogenous variables were captured in the model. Therefore, we considered that the relationships among the variables in the model were stable, and that the proposed model had good explanatory power.

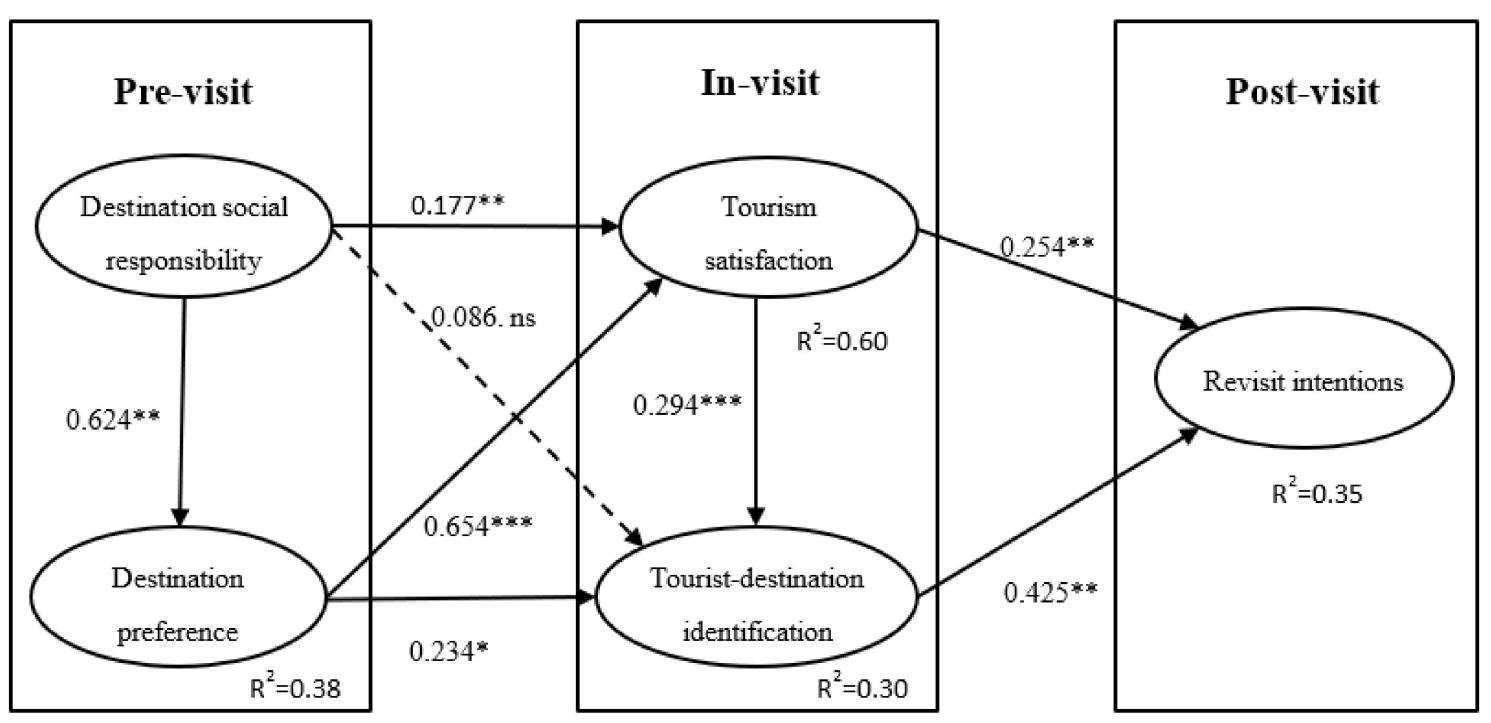

Figure 2. The results of the structural model.

\subsection{Mediating Effect Analysis}

To further confirm the influencing mechanism of destination social responsibility on revisit intentions, we analyze the mediating effect and multiple mediating effects (destination preference, tourist satisfaction, tourist-destination identification as the mediators) using the bootstrap method. We set the number of bootstrap samples as 2000, with a confidence level of $95 \%$. Then, we tested specific indirect effects in Amos 22.0, and calculated the total mediating effect to test the mediation hypotheses. The results are shown in Table 5.

Table 5. The results of multiple mediating effects.

\begin{tabular}{cccc}
\hline Paths & Indirect Effects & Lower Bound 95\% BC & Upper Bound 95\% BC \\
\hline $\mathrm{DSR} \rightarrow \mathrm{TS} \rightarrow \mathrm{RI}$ & 0.0450 & 0.0018 & 0.1229 \\
$\mathrm{DSR} \rightarrow \mathrm{TI} \rightarrow \mathrm{RI}$ & 0.0366 & -0.0095 & 0.1037 \\
$\mathrm{DSR} \rightarrow \mathrm{DP} \rightarrow \mathrm{TS} \rightarrow \mathrm{RI}$ & 0.1037 & 0.0369 & 0.2105 \\
$\mathrm{DSR} \rightarrow \mathrm{DP} \rightarrow \mathrm{TI} \rightarrow \mathrm{RI}$ & 0.0621 & 0.0145 & 0.1503 \\
$\mathrm{DSR} \rightarrow \mathrm{DP} \rightarrow \mathrm{TS} \rightarrow \mathrm{TI} \rightarrow \mathrm{RI}$ & 0.0510 & 0.0113 & 0.1306 \\
\hline
\end{tabular}

Notes: DSR: destination social responsibility; DP: destination preference; TS: tourist satisfaction; TI: tourist-destination identification; RI: revisit intentions.

The lower bound 95\% bias-corrected (BC) to the upper bound 95\% BC of paths of $\mathrm{DSR} \rightarrow \mathrm{TS} \rightarrow \mathrm{RI}, \mathrm{DSR} \rightarrow \mathrm{DP} \rightarrow \mathrm{TS} \rightarrow \mathrm{RI}, \mathrm{DSR} \rightarrow \mathrm{DP} \rightarrow \mathrm{TI} \rightarrow \mathrm{RI}, \mathrm{DSR} \rightarrow \mathrm{DP} \rightarrow \mathrm{TS} \rightarrow \mathrm{TI} \rightarrow \mathrm{RI}$ do not include 0 , which means that the four paths are significant. There, the effect of destination social responsibility on revisit intentions may firstly be mediated by destination preference, and secondly, mediate by tourist satisfaction, and thirdly, mediate by tourist-destination identification. On the contrary, the lower bound $95 \% \mathrm{BC}$ to upper bound $95 \% \mathrm{BC}$ of paths of $D S R \rightarrow T I \rightarrow R I$ include 0 , which means that the path is not significant. 


\section{Discussion and Conclusions}

\subsection{Conclusions}

Based on the three stages of the formation process of tourists' behaviors and relationship quality theory, the purpose of the current study was to investigate and identify the influencing mechanism of DSR on revisit intentions. The empirical findings generally support the integrated model.

With regard to the role of DSR, the findings show that DSR positively impacts destination preference, and tourist satisfaction, but it does not significantly affects tourist-destination identification. Destination preference positively influences both the components of the relationship quality constructs, i.e., tourist satisfaction, and tourist-destination identification.

With regard to the internal relationship between the two relationship quality constructs, the result suggests that tourist satisfaction can improve tourists' identification with the destination. Regarding the relationship between relationship quality and revisit intentions, the empirical results demonstrate that both tourist satisfaction and identification positively impact revisit intentions.

Further, the results of the mediating and multiple mediating analyses suggest that relationship quality constructs have important mediating roles between DSR, destination preference and revisit intentions. The four mediating paths are confirmed: (1) $D S R \rightarrow T S \rightarrow R I$; (2) $D S R \rightarrow D P \rightarrow T S \rightarrow R$; (3) $D S R \rightarrow D P \rightarrow T I \rightarrow R I$; (4) DSR $\rightarrow D P \rightarrow T S \rightarrow T I \rightarrow R I$.

\subsection{Theoretical Implications}

With the intensification of the destination, it is very important to attract and maintain visitors to strengthen the competitive power of the destination. Thus, it needs a theoretical justification for a loyalty formulation, to explore the driving factors of tourist loyalty [4]. However, few previous studies have constructed an integrated model to investigate the antecedents of tourist loyalty based on tourists' decision-making process [4]. To fill this gap, this study divided the formation process of tourist revisit intentions into three stages (pre-visit, in-visit, and post-visit) and constructed an integrated model where DSR and destination preference represents pre-visit variables, relationship quality (tourist satisfaction and identification) represents the in-visit variable, and revisit intentions belong to post-visit. Therefore, this integrated model extends the previous frameworks of destination loyalty behaviors $[4,5]$.

These findings also enrich CSR and brand preference literature, and contribute to tourist loyalty research. Though the marketing literature has widely confirmed that the roles of CSR and brand preference are vital predictors of customer behaviors [8,26], few studies have examined their roles in the tourism destination context [4]. Based on the previous marketing literature, this study adopted DSR and destination preference as the antecedents of revisit intentions. The results confirmed that DSR and destination preference directly impact on revisit intentions via relationship quality constructs.

Relational marketing studies have widely confirmed the roles of customer satisfaction and identification to customer loyalty $[10,13,14]$. Customer satisfaction and identification are viewed as two important relational constructs that can predict customer behaviors well $[10,13,15]$. However, tourism studies have generally ignored the role of tourist identification [14]. Therefore, this study fills in the research gap by providing an empirical validation that tourists do identify with the destination and would like to revisit. Especially, we demonstrated that tourist satisfaction and identification mediate the effect of DSR and destination preference on revisit intentions. Since only a few studies have examined the impacts of DSR on tourist behavior, this study contributes to the body of knowledge by explaining the roles of DSR and tourist-destination relationship quality from a social identity perspective [14].

Moreover, these findings extend prior studies of tourist decision-making [4]. Previous studies have investigated the driving factors of tourist loyalty $[3,5,48,76]$. However, most of these studies have ignored the internal relationships among the factors. This study divided the formation process of tourist revisit intentions into three stages: pre-visit, in-visit, and post-visit. Based on this, the current 
study empirically examines the internal relationship between driving factors. The results confirmed that DSR impacts revisit intentions via four mediating paths, which well represent the formation process of revisit intentions.

\subsection{Managerial Implications}

The results of this paper have important implications for the management of the formation process of tourist behaviors, especially loyal behavior.

Traditionally, marketers use CSR initiatives to establish a positive company reputation or image $[17,18]$. By adopting the CSR concept into the context of destination marketing, the present study opens avenues for exploring a broader issue of social responsibility for destination marketing organizations. Using empirical data collected from an urban tourism attraction in China, this study helps all destination stakeholders to better understand how DSR may contribute to eliciting destination preference, strengthening relationship quality (tourist satisfaction, tourist-destination identification), and subsequently promoting tourist revisit intentions in the Chinese context. DMOs should consider taking more action to implement DSR strategies. Since DSR initiatives aim to produce positive impacts on the whole society [7], the DSR strategies cover a wide range of areas such as philanthropy, volunteerism, ethical labor practices, environmental efforts, and so on. DMOs should increase the DSR investment and integrate it into long-term strategic planning, because tourists' perceptions of DSR are the important source of improving tourist loyalty. DMOs should consider taking more actions to promote DSR initiatives, and inform tourists about the updates of their DSR initiatives. For example, DMOs must unite other stakeholders to collectively implement DSR initiatives, because tourists' perception of DSR would influence their revisit intention, which in turn impacts long-term market growth. From this perspective, DMOs should create various communication channels, especially use modern Internet communication ways, such as micro-blog, Twitter, and WeChat. These channels that make DSR initiatives more genuine, cooperative, and realistic from competitors will considerably strengthen the firm's attractiveness, and thus improve their competitive advantage.

This study found that destination preference directly affects tourist satisfaction, and that tourist-destination identification, in turn, leads to tourist loyalty. Therefore, managers and marketers should not just focus on attracting tourists to visit. DMOs should recognize the importance of destination preference, and put efforts on establishing tourists' destination preferences in their marketing campaigns. DMOs needs to find out their own characteristics, and create a unique brand that distinguishes them from their competitors. For example, communicating the efforts of DSR initiatives with tourists can help to promote destination preference among tourists. In addition, destination preference can be used to evaluate the performance of destination marketing [4].

The findings show that the relationship quality constructs between tourists and the destination has important roles. Thus, DMOs will try to construct a good relationship with tourists, provide satisfactory tourism experience, and strengthen tourist identification with the destination. In the process of tourist satisfaction strategy, managers and marketers should provide satisfactory tourism experiences, and monitor the change of tourist satisfaction. Especially, DMOs should pay attention to DSR activities and destination preferences to improve tourist satisfaction for DSR and destination preference, as these are the antecedents of tourist satisfaction. As social media (e.g., Facebook, TripAdvisor) has made it easier for a dissatisfied tourist to share his/her dissatisfied tourism experience with others beyond his/her immediate communities, it is valuable for managers and marketers to monitor the factors leading to dissatisfaction.

Given the mediating role of tourist-destination identification, it would be wise to develop an identification-building strategy to plan effective ways to support tourists' self-identificational needs. For example, DMOs would select appropriate marketing channels to communicate with tourists and to make tourists feel that the destination brand shares something similar with their views of value. In addition, DMOs could monitor tourists' feedbacks across all marketing channels and respond to 
tourists in a prompt and persuasive manner [15]. DMOs need to focus on shaping meaningful and sustained tourist-destination interactions that make tourists feel like a member of the destination community [15]. For example, DMOs can offer opportunities to invite tourists to participate in some of their DSR activities, and to recognize the tourist's role in co-creating a sustainable destination, which would enable tourists to develop a sense of destination identification.

\section{Limitations and Future Research Directions}

This study has several limitations that might be addressed in further research. First, the present study examined its hypothesis with domestic Chinese tourists, using a convenience sample. We suggest future research utilizing random sampling techniques, as well as a more geographically and ethnically diverse population, to verify the relationship proposed in this study. Second, destination social responsibility is a multi-dimension construct [7]. In order to simplify the model, this study uses each item to represent one dimension of destination social responsibility, and measures it as a whole. Further studies can analyze each dimension's role in the model, and explore their different roles in the model. Third, since DSR measures the collective efforts of all stakeholders from the tourists' perspective, the DSR scale does not investigate which stakeholder is doing well or poorly. Therefore, future research could conduct in-depth interviews with tourists to explore more specific insights into the DSR activities of each destination stakeholder. Finally, the culture and tourist types may be important moderators, which leads to the findings of the present study not being generalizable to other culture and tourism settings [99]. Future research can examine the model in other culture and tourism settings to test the generalizability of the results.

Author Contributions: Conceptualization, L.S. and Y.H.; Methodology, L.S. and Y.H.; Software, L.S.; Validation, L.S.; Formal Analysis, L.S.; Investigation, L.S.; Resources, L.S. and Y.H.; Data Curation, L.S.; Writing-Original Draft Preparation, L.S. and Y.H.; Writing-Review \& Editing, Y.H.; Visualization, L.S. and Y.H.; Supervision, L.S. and Y.H.; Project Administration, L.S.; Funding Acquisition, L.S.

Funding: This research was supported by the National Science Foundation of China (No. 71573279; 71774176), the State Key Program of the National Natural Science of China (No. 71431006), and the National Science Foundation of Distinguished Young Scholars of Hunan Province (No. 2017JJ1032).

Conflicts of Interest: The authors declare no conflict of interest.

\section{References}

1. Nunkoo, R.; Ramkissoon, H. Developing a community support model for tourism. Ann. Tour. Res. 2011, 38, 964-988. [CrossRef]

2. Kang, S.K.; Lee, J. Support of marijuana tourism in Colorado: A residents' perspective using social exchange theory. J. Destin. Mark. Manag. 2018, 9, 320-319. [CrossRef]

3. Hutchinson, J.; Lai, F.; Wang, Y. Understanding the relationship of quality, value, equity, satisfaction, and behavioral intentions among golf travelers. Tour. Manag. 2009, 30, 298-308. [CrossRef]

4. Mao, R.Y.; Zhang, H.Q. Structural relationships among destination preference, satisfaction and loyalty in Chinese tourists to Australia. Int. J. Tour. Res. 2014, 16, 201-208. [CrossRef]

5. Su, L.; Hsu, M.R. Service fairness, consumption emotions, satisfaction, and behavioral intentions: The experience of Chinese heritage tourists. J. Travel Tour. Mark. 2013, 30, 786-805. [CrossRef]

6. Luo, X.; Bhattacharya, C.B. Corporate social responsibility, customer satisfaction, and market value. J. Mark. 2006, 70, 1-18. [CrossRef]

7. Su, L.; Swanson, S.R. The effect of destination social responsibility on tourist environmentally responsible behavior: Compared analysis of first-time and repeat tourists. Tour. Manag. 2017, 60, 308-321. [CrossRef]

8. Liu, M.T.; Wong, I.A.; Shi, G.; Chu, R. The impact of corporate social responsibility (CSR) performance and perceived brand quality on customer-based brand preference. J. Serv. Mark. 2014, 28, 181-194.

9. Taylor, G.A. Coupon response in services. J. Retail. 2001, 77, 139-151. [CrossRef]

10. Kim, W.G.; Cha, Y. Antecedents and consequences of relationship quality in hotel industry. Int. J. Hosp. Manag. 2002, 21, 321-338. [CrossRef] 
11. Reichheld, F.F.; Sasser, W.E. Zero defections: Quality comes to services. Harv. Bus. Rev. 1990, 68, $105-111$. [PubMed]

12. Meng, J.; Elliott, K.M. Predictors of relationship quality for luxury restaurants. J. Retail. Consum. Serv. 2008, 15, 509-515. [CrossRef]

13. Crosby, L.A.; Evans, K.A.; Cowles, D. Relationship quality in services selling: An interpersonal influence perspective. J. Mark. 1990, 54, 68-81. [CrossRef]

14. Su, L.; Swanson, S.R.; Chen, X. The effect of perceived service quality on repurchase intentions and subjective well-being of Chinese tourists: The mediating role of relationship quality. Tour. Manag. 2016, 52, 82-95. [CrossRef]

15. Bhattacharya, C.B.; Sen, S. Consumer-company identification: A framework for understanding consumers' relationships with companies. J. Mark. 2003, 67, 76-88. [CrossRef]

16. Martínez, P.; del Bosque, I.R. CSR and customer loyalty: The roles of trust, customer identification with the company and satisfaction. Int. J. Hosp. Manag. 2013, 35, 89-99. [CrossRef]

17. Romani, S.; Grappi, S. How companies' good deeds encourage consumers to adopt pro-social behavior. Eur. J. Mark. 2014, 48, 943-963. [CrossRef]

18. Bagozzi, R.P.; Grønhaug, K. The role of moral emotions and individual differences in consumer responses to corporate green and non-green actions. J. Acad. Mark. Sci. 2015, 43, 333-356.

19. Huntley, J.K. Conceptualization and measurement of relationship quality: Linking relationship quality to actual sales and recommendation intention. Ind. Mark. Manag. 2006, 35, 703-714. [CrossRef]

20. Su, L.; Huang, S.; Huang, J. Effects of destination social responsibility and tourism impacts on residents' support for tourism and perceived quality of life. J. Hosp. Tour. Res. 2018, 42, 1039-1057. [CrossRef]

21. Lee, S.; Seo, K.; Sharma, A. Corporate social responsibility and firm performance in the airline industry: The moderating role of oil prices. Tour. Manag. 2013, 38, 20-30. [CrossRef]

22. Su, L.; Swanson, S.R.; Hsu, M.; Chen, X. How does perceived corporate social responsibility contribute to green consumer behavior of Chinese tourists: A hotel context. Int. J. Contemp. Hosp. Manag. 2017, 29, 3157-3176. [CrossRef]

23. Kim, M.; Kim, Y. Corporate social responsibility and shareholder value of restaurant firms. Int. J. Hosp. Manag. 2014, 40, 120-129. [CrossRef]

24. Buhalis, D. Marketing the competitive destination of the future. Tour. Manag. 2000, 21, 97-116. [CrossRef]

25. Tran, H.; Hwang, Y.; Yu, C.; Yoo, S. The Effect of Destination Social Responsibility on Tourists' Satisfaction: The Mediating Role of Emotions. Sustainability 2018, 10, 3044. [CrossRef]

26. Ebrahim, R.; Ghoneim, A.; Irani, Z.; Fan, Y. A brand preference and repurchase intention model: The role of consumer experience. J. Mark. Manag. 2016, 32, 1230-1259. [CrossRef]

27. Banks, S. Relationships between preference and purchase of brands. J. Mark. 1950, 15, 145-157. [CrossRef]

28. Woodside, A.G.; Lysonski, S. A general model of traveler destination choice. J. Travel Res. 1989, $27,8-14$. [CrossRef]

29. Huang, Y.; Huang, F.; Hsu, M.K.; Chang, F. Determinants and outcomes of relationship quality: An empirical investigation on the Chinese travel industry. Asia Pac. J. Tour. Res. 2009, 14, 59-75. [CrossRef]

30. Morgan, R.M.; Hunt, S.D. The commitment-trust theory of relationship marketing. J. Mark. 1994, 58, $20-38$. [CrossRef]

31. Kotler, P.; Bowen, J.; Makens, J. Marketing for Hospitality and Tourism; Prentice-Hall: Englewood Cliffs, NJ, USA, 1996; pp. 350-351.

32. Gabarino, E.; Johnson, M.S. The different roles of satisfaction, trust, and commitment in customer relationships. J. Mark. 1999, 63, 70-87. [CrossRef]

33. Manolis, C.; Weitz, B.A. Relationship quality and buyer-seller interactions in channels of distribution. J. Bus. Res. 1999, 46, 303-313.

34. Dorsch, M.J.; Swanson, S.R.; Kelly, S.W. The role of relationship quality in the stratification of vendors as perceived by customers. J. Acad. Mark. Sci. 1998, 26, 128-142. [CrossRef]

35. Swan, J.E.; Combs, L.J. Product performance and consumer satisfaction: A new concept. J. Mark. 1976, 40, 25-33. [CrossRef]

36. Bramwell, B. User satisfaction and product development in urban tourism. Tour. Manag. 1998, 19, 35-47. [CrossRef]

37. Oliver, R.L. Measurement and evaluation of satisfaction process in retail setting. J. Retail. 1981, 57, $25-48$. 
38. Anderson, E.; Fornell, C.; Lehmann, D. Customer satisfaction, market share, and profitability: Findings from Sweden. J. Mark. 1994, 58, 53-66. [CrossRef]

39. Brewer, M.B. The social self: On being the same and different at the same time. Personal. Soc. Psychol. Bull. 1991, 17, 475-482. [CrossRef]

40. Tajfel, H.; Turner, J.C. The social identity theory of intergroup behavior. In Psychology of Intergroup Relations; Worchel, S., Austin, W.G., Eds.; Nelson-Hall: Chicago, IL, USA, 1985; pp. 6-24.

41. Ashforth, B.E.; Mael, F. Social identity theory and the organization. Acad. Manag. Rev. 1989, 14, $20-39$. [CrossRef]

42. Dutton, J.E.; Dukerich, J.M.; Harquail, C.V. Organizational images and member identification. Adm. Sci. Q. 1994, 39, 239-263. [CrossRef]

43. Bergamu, M.; Bagozzi, R.P. Self-categorization, affective commitment, and group self-esteem as distinct aspects of social identity in the organization. Br. J. Soc. Psychol. 2000, 39, 555-577. [CrossRef]

44. Mael, F.; Ashforth, B.E. Alumni and their alma matter: A partial test of the reformulated model of organization identification. J. Organ. Behav. 1992, 13, 103-123. [CrossRef]

45. Pratt, M.G. To be or not to be: Central questions in organizational identification. In Identity in Organizations: Building Theory Through Conversations; Whetten, D.A., Godfrey, P.C., Eds.; Sage Publications: Thousand Oaks, CA, USA, 1998; pp. 171-207.

46. Zeithaml, V.A.; Berry, L.L.; Parasuraman, A. The behavioral consequences of service quality. J. Mark. 1996, 60, 31-46. [CrossRef]

47. Agustin, C.; Singh, J. Curvilinear effects of consumer loyalty determinants in relational exchanges. J. Mark. Res. 2005, 42, 96-108. [CrossRef]

48. Chen, C.-F.; Chen, F.-S. Experience quality, perceived value, satisfaction and behavioral intentions for heritage tourists. Tour. Manag. 2010, 31, 29-35. [CrossRef]

49. Qu, H.; Kim, L.H.; Im, H.H. A model of destination branding: Integrating the concepts of the branding and destination image. Tour. Manag. 2011, 32, 465-476. [CrossRef]

50. Howard, J.A.; Sheth, J.N. The Theory of Buyer Behavior; John Wiley \& Sons: New York, NY, USA, 1969.

51. Amir, O.; Levav, J. Choice construction versus preference construction: The instability of preferences learned in context. J. Mark. Res. 2008, 45, 145-158. [CrossRef]

52. Lim, Y.; Weaver, P.A. Customer-based brand equity for a destination: The effect of destination image on preference for products associated with a destination brand. Int. J. Tour. Res. 2014, 16, 223-231. [CrossRef]

53. Scott, W.R. The adolescence of institutional theory. Adm. Sci. Q. 1987, 32, 493-511. [CrossRef]

54. Maignan, I.; Ferrell, O.C.; Ferrell, L. A stakeholder model for implementing social responsibility in marketing. Eur. J. Mark. 2005, 39, 956-977. [CrossRef]

55. Daub, C.-H.; Ergenzinger, R. Enabling sustainable management through a new multi-disciplinary concept of customer satisfaction. Eur. J. Mark. 2005, 39, 998-1012. [CrossRef]

56. Sen, S.; Bhattacharya, C.B. Does doing good always lead to doing better? Consumer reactions to corporate social responsibility. J. Mark. 2001, 38, 225-243. [CrossRef]

57. Tajfel, H.; Turner, J.C. An integrative theory of intergroup conflict. In The Social Psychology of Intergroup Relations; Austin, W., Worchel, S., Eds.; Brooks Cole: Monterrey, Mexico, 1979.

58. Perez, A.; del Bosque, I.R. Sustainable development and stakeholder relations management: Exploring sustainability reporting in the hospitality industry from a SD-SRM approach. Int. J. Hosp. Manag. 2014, 42, 174-187. [CrossRef]

59. Romani, S.; Grappi, S.; Bagozzi, R.P. Explaining consumer reactions to corporate social responsibility: The role of gratitude and altruistic values. J. Bus. Ethics 2013, 114, 193-206. [CrossRef]

60. Pérez, A.; del Bosque, I.R. An integrative framework to understand how CSR affects customer loyalty through identification, emotions and satisfaction. J. Bus. Ethics 2015, 129, 571-584. [CrossRef]

61. Scott, S.G.; Lane, V.R. A stakeholder approach to organizational identity. Acad. Manag. Rev. 2000, $25,43-62$. [CrossRef]

62. Matute, J.; Bravo, R.; Pina, J.M. The influence of corporate social responsibility and price fairness on customer behavior: Evidence from the financial sector. Corp. Soc. Responsib. Environ. Manag. 2011, 18, 317-331. [CrossRef] 
63. Hur, W.M.; Kim, H.; Kim, H.K. Does customer engagement in corporate social responsibility initiatives lead to customer citizenship behaviour? The mediating roles of customer-company identification and affective commitment. Corp. Soc. Responsib. Environ. Manag. 2018, 25, 1258-1269. [CrossRef]

64. Jamal, A.; Al-Marri, M. Exploring the effect of self-image congruence and brand preference on satisfaction: The role of expertise. J. Mark. Manag. 2007, 23, 613-629. [CrossRef]

65. Nakra, R. Relationship between communication satisfaction and organizational identification: An empirical study. J. Bus. Perspect. 2006, 10, 41-51. [CrossRef]

66. Bodet, G.; Bernache-Assollant, B. Consumer loyalty in sport spectatorship services: The relationship with consumer satisfaction and team identification. Psychol. Mark. 2011, 28, 781-802. [CrossRef]

67. Arnett, D.B.; German, S.D.; Hunt, S.D. The identity salience model of relationship marketing success: The case of nonprofit marketing. J. Mark. 2003, 67, 89-105. [CrossRef]

68. Hou, J.; Lin, C.; Morais Duarte, B. Antecedent of attachment to a cultural tourism destination: The case of hakka and non-hakka Taiwanese visitors to pei-pu, Taiwan. J. Travel Res. 2005, 44, 221-233. [CrossRef]

69. Hultman, M.; Skarmeas, D.; Oghazi, P.; Beheshti, H.M. Achieving tourist loyalty through destination personality, satisfaction, and identification. J. Bus. Res. 2015, 68, 2227-2231. [CrossRef]

70. De Wulf, K.; Odekerken-Schroder, G.; Iacobucci, D. Investments in consumer relationships: A cross-country and cross-industry exploration. J. Mark. 2001, 65, 33-50. [CrossRef]

71. Henning-Thurau, T.; Gwinner, K.P.; Gremler, D.D. Understanding relationship marketing outcomes: An integration of relational benefits and relationship quality. J. Serv. Res. 2002, 4, 230-247. [CrossRef]

72. Palmatier, R.W.; Dant, R.P.; Grewal, D.; Evans, K.P. Factors influencing the effectiveness of relationship marketing: A meta-analysis. J. Mark. 2006, 70, 136-153. [CrossRef]

73. Petrick, J.F. The roles of quality, value, and satisfaction in predicting cruise passengers' behavioral intentions. J. Travel Res. 2004, 24, 397-407. [CrossRef]

74. Prayag, G.; Ryan, C. Antecedents of tourists' loyalty to Mauritius: The role and influence of destination image, place attachment, personal involvement, and satisfaction. J. Travel Res. 2012, 51, 342-356. [CrossRef]

75. Loureiro, S.M.C.; Kastenholz, E. Corporate reputation, satisfaction, delight, and loyalty towards rural lodging units in Portugal. Int. J. Hosp. Manag. 2011, 30, 575-583. [CrossRef]

76. Abou-Shouk, M.A.; Zoair, N.; EI-Barbary, M.N.; Hewedi, M.M. The sense of place relationship with tourist satisfaction and intentional revisit: Evidence from Egypt. Int. J. Tour. Res. 2018, 20, 172-181. [CrossRef]

77. Ahearne, M.; Bhattacharya, C.B.; Gruen, T. Antecedents and consequences of customer-company identification: Expanding the role of relationship marketing. J. Appl. Psychol. 2005, 90, 574-585. [CrossRef] [PubMed]

78. He, H.; Li, Y.; Harris, L. Social identity perspective on brand loyalty. J. Bus. Res. 2012, 65, 648-657. [CrossRef]

79. Marin, L.; Ruiz, S.; Rubio, A. The role of identify salience in the effects of corporate social responsibility on consumer behavior. J. Bus. Ethics 2009, 84, 65-78. [CrossRef]

80. Perez, A.; García de los Salmones, M.M.; Rodríguez del Bosque, I. The effect of corporate associations on consumer behavior. Eur. J. Mark. 2012, 47, 218-238. [CrossRef]

81. Turner, J.C.; Hogg, M.A.; Oakes, P.J.; Reicher, S.D.; Wetherell, M.S. Rediscovering the Social Group: A Self-Categorization Theory; Blackwell: Oxford, UK, 1987.

82. Kumar, V.; Kaushik, A.K. Destination brand experience and visitor behavior: The mediating role of destination brand identification. J. Travel Tour. Mark. 2018, 35, 649-663. [CrossRef]

83. De Bloom, J.; Geurts, S.A.E.; Taris, T.W.; Sonnentag, S.; de Weerth, C.; Kompier, M.A.J. Effects of vacation from work on health and wellbeing: Lots of fun, quickly gone. Work Stress Int. J. Work Health Organ. 2010, 24 , 196-216.

84. De Bloom, J.; Geurts, S.A.E.; Sonnentag, S.; Taris, T.W.; de Weerth, C.; Kompier, M.A.J. How does a vacation from work affect employee health and well-being? Psychol. Health 2011, 26, 1606-1622. [CrossRef]

85. Fritz, C.; Sonnentag, S. Recovery, well-being, and performance-related outcomes: The role of workload and vacation experiences. J. Appl. Psychol. 2006, 91, 936-945. [CrossRef]

86. Gilbert, D.; Abdullah, J. Holiday taking and the sense of well-being. Ann. Tour. Res. 2004, 13, $103-121$. [CrossRef]

87. Dahlsrud, A. How corporate social responsibility is defined: An analysis of 37 definitions. Corp. Soc. Responsib. Environ. Manag. 2008, 15, 1-13. [CrossRef] 
88. Su, L.; Huang, S.; Pearce, J. How does destination social responsibility contribute to environmentally responsible behaviour? A destination resident perspective. J. Bus. Res. 2018, 86, 179-189. [CrossRef]

89. Brown, J.T.; Cowles, D.L.; Tuten, T.L. Service recovery: Its value and limitations as a retail strategy. International J. Serv. Ind. Manag. 1996, 7, 32-46. [CrossRef]

90. Su, L.; Hsu, M.K.; Swanson, S. The effect of tourist relationship perception on destination loyalty at a world heritage site in China: The mediating role of overall destination satisfaction and trust. J. Hosp. Tour. Res. 2017, 41, 180-210. [CrossRef]

91. Nunally, J.C. Psychometric Theory, 2nd ed.; McGraw-Hill: New York, NY, USA, 1978.

92. Anderson, J.C.; Gerbing, D.W. Structural equation modeling in practice: A review and recommended two-step approach. Psychol. Bull. 1988, 103, 411. [CrossRef]

93. Chang, S.-J.; Witteloostuijn, A.; Eden, L. From the Editors: Common method variance in international business research. J. Int. Bus. Stud. 2010, 41, 178-184. [CrossRef]

94. Kline, R.B. Principles and Practice of Structural Equation Modeling; Guilford: New York, NY, USA, 1998.

95. Hu, L.T.; Benter, P.M. Cutoff criteria for fit indexes in covariance structure analysis: Conventional criteria versus new alternatives. Struct. Equ. Model. 1999, 6, 1-55. [CrossRef]

96. Fornell, C.; Larcker, D.F. Evaluating structural equation models with unobservable variables and measurement error. J. Mark. Res. 1981, 18, 39-50. [CrossRef]

97. Hair, J.F.; Anderson, R.E.; Tatham, R.L.; Black, W.C. Multivariate Data Analysis; Prentice Hall: Englewood Cliffs, NJ, USA, 1998.

98. Cohen, J. Statistical Power Analysis for the Behavioral Sciences, 2nd ed.; Lawrence Erlbaum Associates Publishers: Hillsdale, NJ, USA, 1988.

99. He, X.; Hu, D.; Swanson, S.R.; Su, L.; Chen, X. Destination perceptions, relationship quality, and tourist environmentally responsible behavior. Tour. Manag. Perspect. 2018, 28, 93-104. [CrossRef]

(C) 2018 by the authors. Licensee MDPI, Basel, Switzerland. This article is an open access article distributed under the terms and conditions of the Creative Commons Attribution (CC BY) license (http://creativecommons.org/licenses/by/4.0/). 